\title{
THE MEDICINE OF THE PROPHET
}

\author{
by \\ GYRIL ELGOOD
}

IN the year A.D. 1658 died Hájji Khalífa, the great bibliographer, whose Kashaf-ul-Zanuin contains the titles, arranged alphabetically, of all the Arabic, Persian and Turkish books of which the existence was known to him. $\mathrm{He}$ also attempted to classify them by their subject matter. And among the sub-divisions of works on Medicine is to be found a speciality which he entitled Tibb-ulNabbí or Medicine of the Prophet.

This minor speciality is to my mind of great importance to medical historians, for it shows the state of medical knowledge in the desert among the Bedouins of that day, the extent to which foreign ideas (that is, Greek, Persian and Indian) had penetrated Central Arabia in the sixth century. And of course the prestige of the speaker must have added considerable importance to these views in later Islamic times.

In the days when Hájji Khalifa wrote he was able to record seven different works, all bearing the title $\overline{T i b} b$-ul-Nabbi and all purporting to give the ipsissima verba and views of the Prophet on various aspects of Medicine. These seven works are by Abu Nu'aym Ahmed of Ispahan, Abu ul-'Abbás Ja'far Mustaghfirí, Jalál-ul-Dín ul-Suyútí, Abu ul-Hassan 'Alí al-Rizá, Habíb Nishápúrí, Habíb ul-Thání, and 'Abd-ul-Malik bin Habíb.

According to Hájji Khalífa 'Alí al-Rizá dedicated his version to the Caliph al-Ma'mun', who reigned from A.D. 833 to 842 . This then is probably the earliest of these versions. I do not know whether any copy of this work is still in existence. I have amused myself by collecting manuscripts on these medical sayings of the Prophet, but I have failed to find the version of al-Rizá.

In this paper I propose to analyse the contents of five versions which I have in my collection. I have also seen a very brief version in the Vatican Library which was composed in the eleventh century A.H., that is, the seventeenth century A.D. I have also an Indian version by Mohamed Akbar Arzání, composed in A.D. I 700, which has been lithographed in Bombay. As the former of these versions consists only of a few pages and the latter is based on the version of al-Suyútí whose work I shall describe below, I have not unduly prolonged the article by analysing them.

The oldest version in my collection is that of $\mathrm{Abu} \mathrm{Nu}$ 'aym. A good deal is known about the author and a good deal must be added here. For it is upon his work that most of the later versions of the $\mathcal{T} i b b-u l-N a b b i$ are constructed.

The exact dates of his birth and his death are uncertain. Tradition claims that he was born A.D. 936/7. The two famous biographers, Ibn Khallikán and Hájji Khalífa, state that he died in A.D. 1038/9. But Ibn ul-Júzi gives the date of his death as A.D. IOI I, and adds that he was seventy-seven years of age. On the other hand the author of the Tárikh-i-Akhbar-ul-Bashr puts his death more 146 


\section{The Medicine of the Prophet}

than a century later, that is, in A.D. I I23. The manuscript which I am about to describe, contains the sentence 'I was present in the year A.H. 5 I2 (that is, A.D. I I I8) when our Patron the Imam Abu Nu'aym said ... ' If this date is correct, then the classical biographers are wrong and the author of the Tárikh is probably correct.

It has also been said that $\mathrm{Abu} \mathrm{Nu}$ 'aym attended the evening classes of Avicenna when this celebrated teacher was living in Ispahan. We know that he took up residence in Ispahan during the last years of his life and, as he died in A.D. I036, if this tradition is correct, it is a point against the author of the Tárikh and in favour of the early biographers. Mr. Sadr Háshimí, who has recently made a special study of $\mathrm{Abu} \mathrm{Nu}$ 'aym, accepts the earlier date as being the more likely to be correct.

Some writers have spelt his name Naim, but it is now generally recognized that the correct transliteration is NU'AYM. There is today a lane in Ispahan which is called Abu Nu'aym Street. It contains the tomb of a prominent Sufi shaykh and is thought to be the district in which Abu Nu'aym lived and died. Local superstition maintains that a certain Mohamed Báqir, a prominent shaykh and a prolific writer in the Safavid times (roughly corresponding to our Elizabethan era), still visits the tomb on a Friday evening to pray. Whether this can be construed into evidence for the abiding spirit of Abu Nu'aym I cannot say.

Mr. Mohamed Sadr Háshimí, whom I have just mentioned and who is now the headmaster of one of the leading High Schools in Ispahan, writes as follows about the grave:

In the quarter called Dár-i-Shaykh, close to the Áb-bakhshán Cemetery there used to be a large garden from the ruins of which one could picture that in the past there must have been a large building within. At one side of the garden adjoining the wall there was a small prominence. On this prominence there were the remains of a tomb which people said was the grave of Háfiz Abu Nu'aym, who was the grandfather of Majlisi from whom visitors came to implore a blessing. On this tomb there used to be a marble stone covering it, with an inscription. At the present day there is no trace of the tomb nor of its marble. The garden itself has been converted into a new housing estate. (Personal communication.)

The inscription, however, has been preserved. It is in Arabic, names Abu $\mathrm{Nu}$ 'aym as the occupier of the tomb, but gives no date.

Besides the Tibb-ul-Nabbi, Abu Nu'aym wrote a History of Ispahan, which has been printed and published in Germany, a book on Sufiism called the Adornment of the Saints, which has been printed and published in Egypt, and three other works (unprinted as far as I know) which from their titles would seem also to be concerned with the doctrines and practice of Sufiism.

His Tibb-ul-Nabbi has, as far as I know, never been printed and its contents are known only from a single manuscript, now preserved in the Escorial library. The general tone of the work is religious and legalistic rather than devotional or medical. Emphasis is laid on the authenticity of each remark attributed to the Prophet and a long chain of authorities is given for every statement.

The book itself was put into its present form by Abu ul-Hajjáj Yúsuf bin 


\section{Cyril Elgood}

al-Khalíl of Damascus, who flourished about A.D. 1240. This last date should therefore be taken as the date of the composition of the book. It throws no light on the date of the birth and death of Abu-Nu'aym.

Analysing the Escorial manuscript it becomes evident that the book is divided into seven sections. Section One is on the knowledge and excellence of Medicine in general. It deals with such topics as the education of a doctor (Ch. I), the practice of Medicine by females (Ch. 5), and the penalties for improper practices (Ch. 7).

In Section Two the Preservation of Health is the general theme, e.g. how to site a house (Chs. 13, I4 and 16) and on the need for sleep (Ch. 19).

Section Three deals with Disease and contains a large discourse on Leprosy (Ch. 28-34), the usual disquisition on sexual intercourse (Ch. 8I-83), and a very interesting discussion on the nursing of men by women (Ch. 89).

Section Four is short and not very interesting to the general reader. It deals only with aromatic roots and their uses.

Section Five deals with the convalescent patient and unfortunately breaks off in the middle of Chapter 16 . How much more there is of this section cannot be known until another manuscript is discovered.

Section Six deals with Habits, and Section Seven with Charms. But both are missing. As the writer of the manuscript (as opposed to the author) always puts his name and the date of his copying the manuscript on the last page, these too remain unknown.

From Abu Nu'aym I turn to the next version in my collection. Here we find a very different type of work. The old pious desire for authority is missing. Anecdotes are frowned upon. The collection has become almost a textbook of practical Medicine.

This version was composed by Ibn Qayyam al-Júziyya, who died in A.H. 75I, that is, A.D. I350/I. According to the Kashaf-ul-Zanún al-Júziyya was a practising physician, a fact which no doubt coloured his version of the Tibb-ul-Nabbi. $\mathrm{He}$ also wrote a Compendium of Medicine which he called $A l-D a$ ' wa al-Dawa, that is, 'The Disease and its Remedy'. However, his Tibb-ul-Nabbi is not mentioned in the Kashaf-ul-Zanún, which at first is a matter of astonishment.

The answer to the problem has been supplied by the editor of the printed edition of the work. This edition was printed in Aleppo in A.D. 1927 and can still be purchased in the bazaar there. The editor suggests that Hájji Khalífa was ignorant of the existence of this collection of Prophetic medical sayings because it lies hidden within another work of the same author which Hájjí Khalifa had not read. For al-Júziyya also wrote a large book which he entitled $\bar{Z} \dot{a} d-u l-M^{\prime}$ 'd fi Hadi Khayr-il-'Abád or 'The Victuals of Pilgrimage and the Guide to the Good of mankind'. This was published in Cairo in A.D. I906 and there within lies a large section on Prophetic Medicine which has now been extracted and published separately with no acknowledgment (until the 1927 edition) that it forms part of a larger work.

The Tibb-ul-Nabbi of al-Júziyya contains 277 chapters. The subject matter there dealt with varies from the treatment of individual diseases as recommended $\mathrm{I} 48$ 


\section{The Medicine of the Prophet}

by the Prophet to medico-legal matters, such as malpractice, hallmarks of a competent doctor, and so forth. Many of these traditions must be spurious. It is inconceivable that the Prophet had a knowledge so wide or that his remarks upon so many trivial diseases should have been remembered. The element of magic in the book is small, although the treatment for the evil eye has a long section and in certain cases written charms are recommended.

As an example of the pathology of al-Júziyya, and surely it is his and not the Prophet's, I quote a short section from his chapter on ophthalmia.

Know then that there arises from the ground to the sky two vapours, one of them hot and dry, the other hot and damp. Their gathering forms a heavy cloud such as to prevent us from seeing the sky. Sometimes something similar to this rises from the Greater Curvature of the Stomach along all its length and interferes with vision. From this is generated severe disease.

When Nature is the stronger, it expels these vapours to the back of the nose and there sets up a Nasal Catarrh. If the vapours are expelled to the uvula and the nostrils, a Quinsey is caused. If to the side an Empyema; if to the chest a Pneumonitis: and if to the heart an Angina. Should the vapours be expelled to the eye, then an Ophthalmia is caused. (Chapter 7I, p. 72.)

Rather a different style is his defence of the use of prayer, charms and incantations instead of vegetable drugs.

It has already been said that there is a greater difference between the Medicine of Physicians and the Medicine of the Prophet than there is between the Medicine of Physicians and the Medicine of itinerant quacks and old women. There is a greater difference between Medicine discovered by Revelation and Medicine discovered by Experience and Guess work than there is between the Medicine of ancient days and the Medicine of our times.

The sayings of the best of doctors, however dogmatic they be, depend upon temperament, time, place and custom. And if these limitations do not limit their speech and their knowledge, how can the sayings of the All-Truthful One be limited? For mankind is made up of ignorance and tyranny, excepting only those to whom God has given the soul of Faith and the power of seeing the guiding light. (Chapter 189, p. 237.)

His description, too, of how to distinguish a specialist makes amusing reading. It occurs in his discussion on malpractice and the fines which are applicable to the different types of doctors.

In this tradition a physician is one who makes use of prescription and talk. He is called a general physician. If he uses a collyrium bodkin, he is an oculist; if he uses scalpels and pastes, he is a surgeon. If he uses a razor, he is a circumciser. If he uses sutures, he is a phlebotomist. If he uses cupping glasses and lancets, then he is a scarifier. If he uses a retractor and a coupler and ropes, then he is a bone-setter. If he uses a cautery, then he is a brander. And if he employs water-bags, then he is a giver of enemas. But Medicine is the same, whether it is for dumb animals or for mankind. In common talk the word doctor is applied to all of these. This giving of different names to the various kinds of doctors is quite new. It is like giving a special name to each animal when the one word animal covers them all. (Chapter 89, p. 96.)

I turn next to the Tibb-ul-Nabbi of al-Suyútí which I find far the most interesting reading. The full name of the author is Jalál-ul-Dín 'Abd-ul-Rahman ibn abi Bakr al-Suyútí. He was born in Suyut in Upper Egypt in A.D. I445. His family originally came from Persia and he also had Turkish blood in him. An infant genius by eight he had the Quran by heart. On reaching manhood he 
was elected to professorship after professorship in Cairo. However, on account of peculation he fell into disgrace and was required to retire into obscurity. He died four years later in A.D. 1505 .

He was a prolific writer on a variety of subjects, writing always in Arabic treatises which varied from philosophy to pornography. His literary output covered the whole field of Moslem science. Among his medical works he wrote a tract on Diseases of Childhood and their cure and another on the Uses of the Depilatory. He composed two works on Prophetic Medicine, one containing the sayings and practices of Mohamed on Medicine in general and a second work entitled Sexual Relations as ordained by the Prophet. He also composed pamphlets on more abstruse subjects connected with the Prophet, e.g. whether he wore trousers or not, whether his turban had a point or not, and whether his parents were in Heaven or Hell.

Al-Suyurtí's version of the sayings of the Prophet on general Medicine is divided into three parts. Part One deals with the theory of Medicine and is concerned with what would be termed today physiology and psychology. Most Arabic writers deal with these subjects in a rather uninteresting manner, repeating and copying what has been said on the subject by their predecessors. Al-Suyútí on the contrary makes the subject live. He embellishes his account with quotations from the classics and with remarks drawn from the Prophet and the Commentators.

Among the Hippocratic stories is the following:

A physician was once visiting a sick man and said to him: You, the sickness and I are three. If by hearkening to me you help me, then we shall be two against one and thus the stronger. And when two come against one, they always are the victors.

Again, Hippocrates was asked: Why does a man when dead weigh more than when he was alive? He replied: Once he was made up of two parts, a light part which lifted up and a heavy part that weighed down. When one of these two parts went away, and it was the light part that does the lifting that went, then the heavy part weighed down yet more.

Part One is followed by a relatively dull Part Two which deals with Drugs. But anyone who has struggled to read the pharmacopoeial sections of any of the great Persian and Arabic standard medical works, will find that again al-Suyútí has made this subject of interest by means of anecdotes and historical observations.

The most interesting part of the book is Part Three, which deals with the sayings of the Prophet on a variety of subjects. Thus, he discusses When to call in a Doctor (Ch. 3), Proper Fees for Doctors (Ch. 6), Women Practitioners (Ch. 8) and Birth Control (Ch. I9). Chapters 20 and 21 are devoted to the evil eye and similar superstitions, and the book is rounded off with a long disquisition on embryology and anatomy. Then, rather as an afterthought, come two more chapters, one on the Effect of Songs on Men and Animals and another on Small Pox and Measles. The last is so unlike the rest of the book that I doubt if it is part of the original work at all. In any case both of the chapters are out of their original place.

This version of the Tibb-ul-Nabbi has the supreme advantage of having been translated into French by Dr. Perron and so is in theory available to any 


\section{The Medicine of the Prophet}

curious reader. It was originally published in La Gazette médicale de l'Algérie and was reprinted as a separate work in Algiers in 1860 . But the book is quite unobtainable now. The only copies that I know of can be seen in London, in Paris, and in Washington. The principal library in each of these cities has one copy. Owing to the rareness of this work and to other minor defects $I$ have prepared another translation, this time into English, which I hope will soon be published.

My fourth version of the $T i b b-u l-N a b b i$ is a small collection of the sayings of the Prophet which deal more or less with matters of health. It is not stated in the text who made this collection, but is has been printed together with the Qdininchi of Mahmúd bin Mohamed al-Ghaghilní. The name suggests that it is of Indian or Turkish origin. My edition was lithographed by Mohamed Hassan al-Kaliyakání and published in Hamadan in A.H. 1306, that is A.D. i $888 / 9$.

Unlike the other three collections that I have discussed this one is too abbreviated to have any characteristic. Of the I4I aphorisms that it contains, the great majority are included in the other collections. In this book there is no attempt to estimate the authenticity of a saying nor to decorate the saying with any kind of anecdote. Some of the sayings (which $I$ have not noticed in any of the other books) are very witty, e.g. 'To eat in public in the bazaar is to act like a buzzing fly' (no. 8), or again 'He who uses two wooden toothpicks is safe from the punishment of the dentist's forceps' (no. 12); or even pithy, e.g. 'Less food, less sin' (no. 23).

It is noticeable that the vast majority of these aphorisms are connected with eating and drinking, a few with women and animals, and none with fighting. Yet all come straight from the desert which shows that the Prophet talked more about what he liked than what he did. Take no. 67, 'There are three things that give joy and fatten the body: sweet scents, soft clothes, and the eating of honey', a saying which may well be the original of another saying attributed to the Prophet: 'Three things delight me-scent, women and the sparkle of the eye in prayer.'

Finally, in my collection of Prophetic Medicine there is one version in Urdu. This is a version composed by Karám-ul-Dín the Preacher, whose date I have not yet discovered. It was lithographed in Lucknow in A.D. I953.

This version differs considerably from the older versions in that it is far less anecdotal, less legalistic, and much more devotional. The author opens with a lengthy introduction to prove the necessity of spiritual healing as well as physical, orthodox drug-taking healing. When he speaks about spiritual healing he certainly includes the spiritual treatment of physical disease. But more particularly he is speaking of diseases which are amenable alone to spiritual cure. Such are Possession by Evil Spirits, the Evil Eye and Enchantment.

The author is careful to point out that physical treatment is just as much obligatory and important in the appropriate diseases as is spiritual treatment in psychological or supernatural disease. In proof he quotes the story of Asáma bin Sharik who said: 


\section{Cyril Elgood}

I approached the Prophet one day when people were asking him: In sickness what drugs should be used? Is there no sin in such use? And the Prophet replied: God has made drugs for His servants because $\mathrm{He}$ has provided for every disease the necessary cure, except the disease of Death.

The book starts with a long discussion on the value of Marriage as a cure for disease in general and enumerates the traditional sayings of the Prophet regarding sexual intercourse and childbirth. This leads on to an even lengthier discussion on the traditions regarding eating and drinking. And these, with a few interpolations on one or two diseases, continue until the end of Part One. In all he reports 102 traditions.

Part Two is extremely interesting, for it is in fact a discussion of the superstitions of the Bedouins in the days of Mohamed. Supernatural cure, says the author, is effected by means of verses, charms, amulets and talismans. Amulets were such things as cowries, claws of wild animals and so on. Such are still used in Persia and Arabia today. Yet the Prophet has said: Charms, amulets and omens are heretical. On the other hand, charms which contained the name of God were allowed and it is said that the Prophet ordered charms to be read out before him and would often sanction the use of them if there was nothing therein to suggest polytheism.

A cure worked by an heretical charm was anathema to the best Moslems. The story is told of a slave of $\mathrm{Abu} \mathrm{Bakr}$, who effected a cure in a non-orthodox manner and was given a goat as a fee. After Abu Bakr had eaten some of the goat, he learned that the cure had been wrought by a polytheistic charm. He at once put his finger into his throat and made himself vomit up what was still in the stomach.

The best of all spiritual medicines or amulets are verses of the Quran itself. Perhaps the most effective is the opening verse, for the Prophet himself said: 'When you go to sleep, recite to yourself the Fatiha (that is, the opening chapter of the Quran) and then say: Verily He is God; and so you will be protected from everything except Death.' Such verses may be recited by the sick man himself or be recited over him or be recited over water which he will then drink or even be written upon a piece of paper which is soaked in water and the inky water drunk by the patient.

Shaykh Abu ul-Qásim al-Qashírí relates: Once my son fell so sick that he was near to death. By chance I saw the Prophet in a dream. So I complained to him of the boy's sickness. Then the Prophet said: 'Why are you so careless about the verses of cure?' And he enumerated six verses. 'Write out these verses, soak the writing in water, and give it to the sick boy to drink.' I did so and the child was at once cured, and became just as though he had never been ill.

Even such a markedly physical disease as is the Plague is best treated by spiritual drugs, says Karám-ul-Dín. For he writes: 'It must also be known that physicians say that to sniff scent or amber or musk gives great benefit in days when the Pestilence is rife.' But theologians have written that it is far more effective in such times to read portions of the Quran over a man than to give 
him scent to smell. For it is written in the Traditions: 'To read the Quran is a sufficiency against sorrow.'

Even camels when struck by the evil eye can be treated by enchantments and will be cured.

Poltergeists appear to be not unknown to these Bedouins.

If a poltergeist or a devil throw a stone at any house, then four iron nails should be taken and the following verse recited over them. Then they should be buried near the house for four days after the prayer has been prayed over each nail twenty-five times. And the prayer is: Surely they will fight a fight and I too will fight a fight. So grant the unbelievers a respite: let them alone for a while. (Quran. Al-Tariq chapter 86, vv. ${ }_{15}$, 16, I7.)

The spiritual sections end on a very worldly note. Tradition No. 47, the last but one, runs as follows: 'To increase wealth. The Prophet said on this subject: When God gives any man wealth and this man says: Thanks be to God, Lord of the Two Worlds, then God will give such a man even more wealth.'

That is as far as my studies in this speciality have gone. No doubt other versions of the $T i b b-u l-N a b b i$ exist both in manuscript and in print. The writer of this paper would be very grateful if any reader would inform him of the existence of other versions. It will be a pleasure to comb the bazaars and libraries of Cairo, Ispahan or Delhi if there is any indication that an unknown and unpublished work on the Medicine of the Prophet is there to be found.

\section{POSTSCRIPT}

Since the above was written, I have found two more versions of the Tibb-ul-Nabbi.

i. Al-Sirr-ul-Mustafá fi Tibb-il-Nabbi, that is, The Secret of the Elected One in the Medicine of the Prophet, by Núr-ul-Dín abu ul-Hassan ibn Jazzar.

This is numbered 3035 in the Catalogue of the Bibliothèque Nationale, Paris, and must certainly be studied.

ii. Risála fi Tibb-il-Nabbí, being a collection of Prophetic sayings on Medicine, collected by Ảbu ul-Qásim al-Nishápúrí. This may well be the version mentioned by Hajji Khalífa under the name of Habíb Nishápúrí.

It is to be found in the Cambridge University Library, No. P. Io (13). I think this so important to the study of the subject that $I$ have asked for a photostat to be made. 